DOI: $\underline{\text { https://doi.org/10.15407/techned2019.01.0 } 85}$

\title{
COMPUTER SIMULATION OF HIGH-VOLTAGE DAC
}

Journal

Publisher

ISSN

Issue

Pages
Tekhnichna elektrodynamika

Institute of Electrodynamics National Academy of Science of Ukraine 1607-7970 (print), 2218-1903 (online)

No 1, 2019 (January/February)

$85-88$

\section{Authors}

Yu.F.Tesik ${ }^{\star}$, O.L.Karasinskii ${ }^{\star \star}$, R.N.Moroz ${ }^{\star \star \star}$

Institute of Electrodynamics of National Academy of Sciences of Ukraine,

pr. Peremohy, 56, Kyiv, 03057, Ukraine,

e-mail: luckyposhta@gmail.com

* ORCID ID : http://orcid.org/0000-0001-6567-1436

** ORCID ID : http://orcid.org/0000-0002-5323-8106

*** ORCID ID : http://orcid.org/0000-0002-4292-8160

\section{Abstract}

A computer model of a high-voltage digital-to-analog converter (HVDAC) for use in portable metrological installations is proposed. The principle of operation is described, the scheme of the model, the output signals are shown, the influence of the discreteness of the HVDAC and the resistance of the access keys on the quality of the output signal is investigated. References 9 , figures 3 , table 1 . 
Key words: reproduction, metrological provision, electricity, power amplifiers, voltage digital-analog conversion, computer simulation.

Received: 02.03 .2018

Accepted: 11.07 .2018

Published: 10.01 .2019

\section{References}

1. Moroz R.N., Tesik Yu.F Comparative analysis of performance measuring power amplifiers applied in generators-calibrators and metrological equipment. Pratsi Instytutu Elektrodynamiky Natsionalnoi Akademii Nauk Ukrainy . 2014. Vol. 37. Pp. 114 - 124. (Rus)

2. Taranov S.G., Karasinskii O.L., Tesik Yu.F., Moroz R.N. Development of principles of construction of switching reference voltages of high-voltage DAC. Tekhnichna Elektrodynamika . 2014. No 4. Pp. 64-66. (Rus)

3. Moroz R.N., Tesik Yu.F. Mathematical model of high voltag DAC for estimation of distortion of the output sinusoidal signal. Tekhnichna Elektrodynamika. 2016. No 3. Pp. 85-90. (Ukr)

4. Chukhlomin I.E. Principles of calibrator AC voltage and current of high accuracy. III nauchnaia konferentsiia aspirantov i doktorantov: Nauchnyi poisk. Tekhnicheskie nauki. Izdatelskii tsentr YuUrGU, 2011. Vol. 2. Pp. 149-151. (Rus)

5. Herniter M.E. Modern system of computer simulation and analysis of electronic devices. Moskva: DMK Pres, 2006. 488 p. (Rus)

6. Lavric H., Voncina D. A precision hybrid amplifier for voltage calibration systems. MIDEM 34(2004)1. Pp. $37-42$

7. Zajec P., Nastran J. Power calibrator using switched mode voltage source. IEEE

Transactions on instrumentation and measurement

. 2000. Vol. 49. No 4. Pp. 790-794. DOI:

https://doi.org/10.1109/19.863926

8. Metrological support of electricity metering devices. URL: http://www.bcdst.kiev.ua/index.ph $\mathrm{p} /$ home/827-2014-08-20-06-55-29

(accessed 07.11.2017) 
9. 6105A, 6100B Elecrtical Power Quality Calibrator. URL: https://eu.flukecal.com/products/ele ctrical-calibration/electrical-calibrators/6105a-6100b-electrical-power-quality-calibrat (accessed 08.11.2017)

PDF 